\title{
The Effect of Human Resources Capacity, Budget Planning, Political Budgeting, and Public Transparency on the APBD Documents and KUA-PPAS's Synchronization in Musi Banyuasin District Government
}

\author{
M. Syuroh \\ College of Social and Political Sciences (STISIPOL Candradimuka Palembang) \\ Jl. Swadaya Sekip Ujung No. 20, Palembang, Indonesia, 30127
}

\begin{abstract}
This study aims to determine the effect of human resources capacity, budget planning, political budgeting, and public transparency on the synchronization between Regional Revenues and expenditures budget (APBD) document and General Policy of Regional Revenues and Expenditures Budget (KUA) and Provisional Budget Ceiling Priority (PPAS) document in Indonesia. The studied objects in this study were councilors and officer/staff involved in the preparation of the Work Plan Budget (RKA) SKPD includes 33 SKPD. The sampling method used census method, where the sample includes 127 peoples. The data obtained was analyzed through multiple linear regression tests. Hypotheses simultaneously and partially tested by $\mathrm{F}$ test and $\mathrm{t}$ test. The results of this study showed that simultaneous variable capacity of human resources, budget planning, political budgeting, and public transparency has a positive and significant impact on the synchronization between APBD documents and KUAPPAS documents. In partial, the capacity of human resources, budget planning, political budgeting, and public transparency has appositive and significant impact on the synchronization between APBD documents and KUA-PPAS documents. The implications of this research can be useful as a conceptual contribution to policy makers, especially in West Lombok Regency Government and Parliament, in which they should be more consistent and have a high commitment dealing with budgeting and KUA-PPAS.
\end{abstract}

Keywords: Indonesia, budget, KUA-PPAS, human resources capacity, budget planning, political budgeting, public transparency

\section{Introduction}

Public sector budgeting is related to the determination of the total allocation funds for each of program and activity in monetary unit. The process organization budgeting of public sector is started while the strategy formulation and strategy planning have been completed. The budgeting steps become very important because the ineffective and not oriented budgeting on the performance can ruin the arranged plans. The budgeting of public sector is an instrument of accountability for the 
management of public funds and the implementation of programs financed from public money [1]. Based on the Regulation of the Minister of the Interior (Permendagri) number 13/2006, the unified budgeting is the preparation of an annual financial plan that is carried out in an integrated manner for all types of expenditure to implement government activities based on the principle of achieving efficient allocation of funds.

The funding mechanism is including several parties which have the different background both from the level of understanding and the interests of the budget. These differences can cause asynchronous in the process of arranging the fund which is the Regional Government Budget (APBD) document and the document of Public Policy APBD (KUA) and interim budget priorities and funding ceilings (PPAS). Asynchronous between APBD documents with the document of KUA-PPAS happened in almost of common occurrence in most of every local government [2].

The research by Amirudin [3] is identifying the factors which influence the sync between the documents is Human resources capacity, budgeting politic, planning and supporting information. The results is reveals while when entering the discussion stage the commissions often found additional activity proposals and requests for a shift in the budget from one activity to another, which in turn led to differences between the APBD document and the KUA-PPAS document [3].

According to Iskandar [4], the human resources capacity is the ability of the executive or legislative member in implementing their respective functions and roles in the process of formulating policies in regional financial management [4]. The quality and capability of Regional Representative Assembly (DPRD) members are also needed so that the activities set forth in the APBD are truly beneficial to the community. The problem often occurs is when the budgeting allocation is still understood as the activity of the distribution of development. Allocation to realize people's welfare has not become a soul in the preparation of the regional budget APBD. The resources needed is not only comes from the member who has high education but is also have the member have a good capacity to be able to conduct the roles and functions that must be carried out properly and optimally. According to Amirudin [3], the main legislative role in the in the political process of drafting APBD is related to the clearance when the discussion KUA-PPAS and in the determination Regional regulation APBD. In the discussion of funding, the executive and legislative made agreements which reach for the politic process in KUA and PPAS references before the budget is determined as a local government so that decisions in allocating complex budgets with budgeting politics that are believed to cause synchronization in the budget allocation namely between documents of APBD with KUA-PPAS Document [3].

Based on the preliminary observation between APBD and KUA-PPAS in 2014 founds some problem that faced in the expenditure management of the Musi Banyuasin Regency Government, among others, understanding and discussion of the APBD is not optimal which is influenced by not yet effective and efficient APBD approval by the Banyuasin Regency DPRD and there are still urgent and strategic activities arising from the district, provincial and government governments the center which was not previously budgeted in the Musi Banyuasin Regency 
Regional Budget. This thing can be accommodated directly in RAPBD Musi Banyuasin district and the level of efficiency and effectiveness of expenditure for each activity carried out by each SKPD is not yet optimal within the Government of Musi Banyuasin Regency. The openness to information obtained by the public in APBD planning only at the beginning of the planning of APBD preparation through Development Planning Conference (musrenbang) at various levels. In APBD's implementation stage of APBD management and the final stage of APBD management information and public involvement are interrupted and not publicly published, although it is able to published but still cannot be understood simply by the community, meaning that the public is only involved during the initial APBD deliberations where the development proposal is based on priority scale directly proposed by the public. However, the implementation of musrenbang that has been prepared based on priority scale is not entirely in accordance with the proposal at the time of the musrenbang.

Thus, in the case, researcher is motivated to do this research in order to get the empirical proof about the influence of human resource capacity, budget planning, budgeting politics, and public transparency on synchronizing APBD documents with KUA-PPAS, this research is also accordance with the previous research about APBD document synchronization with KUA-PPAS Document by Arniati [5] and Iskandar [4] moreover, based on the phenomenon can be seem from budgeting planning that listed to KUA-PPAS as well as the regional regulation draft on APBD there are differences which lea to inconsistency in RPBD of Musi Banyuasin Regency [4; 5].

\section{Theoretical Framework and Hypothesis Development}

\section{Human Resources Capacity}

Human resources refer to the peoples in the organization to reach the organization purpose [6]. The meaning of human resources is entire people incorporated in an organization with their respective roles and contributions affecting the achievement of organizational goals. Human resources must be good enough to obtain a good human resource capacity as well.

According to Iskandar [4], the human resources capacity is the ability from the executive or legislative member in carrying out their respective functions and roles in the process of formulating policies in regional financial management [4]. The human resources capacity is also can be seemed from the extent of the ability of the executive and legislative branches to play a role in the process of policy making in the management of regional finances. The executive and legislative roles in the process of formulating policies in regional financial management, it can be seen from the stages of regional financial management. Based on the regional financial management guidelines which are divided into three stages including the preparation, implementation and evaluation of the regional budget APBD. Thus, the resources needed is not only the member who has high education but also has the good capacity to be able to implement the roles and functions properly and optimally.

Based on the above framework, a hypothesis formulation can be arranged as follows: 
H1: Human resource capacity has a positive effect on synchronizing the APBD Document with the KUA-PPAS Document.

\section{Budget Planning}

Planning can be defined as the way organization determines organizational goals [1]. The planning process in preparation budgeting is based on a series of stages (cycles) that begin in January up to December in the current fiscal year. If the planning at the initial stage is showing bad results, thus it will have a bad impact on the planning of the next stage. The good planning is the core from effective management financial. The regional government cannot get the effective financial management if the system of planning and funding owned is bad. Therefore, in the first step planning is the decisive factor for synchronization between RAPBD and KUA-PPAS. In the first planning, the first thing to do is conducting community aspirations and develops planning meetings (Musrenbang). The citizen participation is aimed to reach the result in accordance with public interest from the performance funds.

The funding process management in performance funding started from the work unit located in Local Government (Pemda), from the budget proposal which is called as Work Planning and Regional Budget Work Unit Budget (RKA-SKPD). RKA-SKPD then researched by executive funding team to assess the eligibility of the accommodation in RAPBD and thus will be submitted to the legislature. Afterward, RAPBD is studied by legislative funding committee and responded by all commissions and factions in the discussion of the budget. In this discussion of funding, executive and legislative makes agreements reached from bargaining (with refer to KUA and PPAS) before the funding determined as regional regulation. The funding is determined to be the basic legislative to implement the supervision and evaluation's function of executive performance in terms of the accountability of regional heads.

Based on the framework above, a hypothesis formulation can be arranged as follows:

H2: funds planning has positive effect on synchronize the document of APBD and KUA-PPAS.

\section{Political Budgeting}

According to Hague, et al 1998 politic is the activity including the way the group reaches collective agreement and binding from the effort to reconcile the differences between the groups. In the governmental view, the politic is connecting with the authority problem, decision making, public policy and allocation or distribution. Therefore, to carry out the general policies related to the arrangement and allocation from the resources is needed power and authority [7].

Iskandar [4] stated that politic has significant effect on synchronize the document of APBD and KUA-PPAS [4]. In this case, it has purpose to achieve collective goals and binding with power, decision making, public policy, allocation and distribution in the process of translating activity plans into financial plans with reference to the KUA and PPAS before the budget is stipulated as a regional regulation. 
The principal agent theory approach, that regional autonomy policy in Indonesia has brought very fundamental changes to the relationship between the Regional Government (executive) and the DPRD (legislative). This shows that there is an agency relationship between the executive and legislative branches.

The important role of the legislature is to represent the interests of the community, empowering the government, and overseeing government performance. These three roles place the legislature capable of having a significant influence on government policy. There are two possible changes that can be made by the legislature to budget proposals submitted by the executive, namely: first, changing the amount of the budget and second, changing the distribution of expenditure in the budget. Based on its role, the executive and legislative also play a role in budget discussions where the executive and legislative parties make agreements reached through the political process with reference to the KUA and PPAS before the budget is determined as a regional regulation in the form of regional budget. Therefore, aside from being an inseparable unit in the management function, budgeting in government institutions is also inseparable from the politics of budgeting. follows:

Based on the above framework, a hypothesis formulation can be arranged as

H3: The politics of budgeting has a positive effect on synchronizing the APBD Document with the KUA-PPAS Document.

\section{Public Transparency}

Sopanah and Mardiasmo [1] stated that transparent budget prepares by the executive should be able to meet the following criteria:

(1) budget policy announcement is available,

(2) Budget documents are available and easily accessible,

(3) Timely accountability reports are available,

(4) Accommodating the voice / proposal of the community,

(5) a system for providing information to the public is available.

Transparency as openness of the government in making regional financial policy policies, so that it can be known and monitored by the DPRD and the public. Transparency in the management of regional finances will ultimately create horizontal accountability between local governments and their communities, thus, he created regional governments are clean, effective, efficient, accountable and responsive to the community's aspirations and interests.

From the above definition it can be conclude that transparency is the openness of government to the public to access information based on the public consideration to be able to know openly and comprehensively the accountability of the government.

Based on the above framework, a hypothesis formulation can be arranged as follows:

H4: Public Transparency has a positive effect on synchronizing APBD Documents with KUA-PPAS Documents. 


\section{Methodology}

The type of this research used associative research, which is aimed to obtain the relationships between one variable with another variable. Afterwards, the relationship used in this study is a causal relationship. This research is used the council members in charge of regional financial oversight and officials / employees involved in the preparation of the RKA-SKPD amounted to 127 peoples from 33 SKPD in the Government of Musi Banyuasin Regency.

Definition operational in each variable that used can be explained:

a) Synchronize the APBD and KUA-PPAS document is dependent variable (Y) in this research. Synchronize is the results of correspondence between documents policy which one is with the other document policy [4]. Synchronize in this research is assessed using with 4 (four) indicators including:

(1) Conformity between the programs in the APBD document and the KUAPPAS document,

(2) Conformity between the activities in the APBD document and the KUAPPAS document,

(3) Conformity between the budget ceiling in the APBD document and the KUA- document PPAS, and

(4) Budget shifts in KUA-PPAS are based on regional financial regulations.

(b) Human resource capacity (X1) is the ability from executive or legislative member in carrying out their respective functions and roles in arranging process policy in regional financial management [4]. Human resources capacity in this research is assessed using with 3 (three) indicators which is:

(1) Knowledge of budgeting,

(2) Understanding in preparing a budget, and

(3) Ability and skills to prepare a budget.

(c) Planning of funds (X2), planning is the way the organization sets organizational goals and objectives. Planning includes activities that are strategic, tactical, and involve operational aspect. The process of planning is also involved behavioral aspect, which is participation in development of planning system, setting goals and the selection of the most appropriate tools to monitories the development to reach the goals [1]. Fund planning is assessed using 2 (two) indicators which are:

(1) Funds planning begin with the implementation of the musrenbang, and (2) Funds planning are carrying out from the coordinate's process.

(d) Funds politic (X3) are how to achieve goals that are collective and binding through power, making decision, public policy allocation and distribution in the process of translating activity plans into financial plans [4]. Politic funds in this research assessed with using 2 (two) indicators which is:

(1) The presence of the important elements during funds, and (2) Bargaining between executive and legislative during funding.

(e) Public transparency (X4) it is defined that there is openness about the budget that is easily accessed by the public quickly [4;8]. Public transparency in this research is assessed with using 5 (five) indicators there are: 
(1) there are budget policy announcements, (2) budget documents are available and easily accessible, (3) timely accountability reports are available, (4) voice accommodation / people's proposals are available, and (5) there is a public information system.

Variable of measurement is using Likert 4 Scale (four) point, which is 1 (Strongly agree), 2(agree), 3 (disagree), 4 (strongly disagree). As stated by Sugiyono [9], Likert scale is used to measure of attitude, opinion, and perception of person or group about social phenomenon.

\section{Data Analysis Method}

This research describes a relationship in which one or more variables (independent variables) affect other variables (the dependent variable). Moreover, multiple linear regression analysis to test the hypothesis is applied in this study. The test is based on the multiple linear regression equation as follows:

$$
\begin{aligned}
& Y=\alpha+\beta_{1} X_{1}+\beta_{2} X_{2}+\beta_{3} X_{3}+\beta_{4} X_{4}+e \\
& \text { Information: } \\
& \text { Y = synchronize documents APBD and KUA-PPAS } \\
& \alpha=\text { Constanta } \\
& \beta_{1} \beta_{2} \beta_{3} \beta_{4} \quad=\text { Regression coefficient for each Variable } X \\
& \mathrm{X}_{1} \quad=\text { Human Resources Capacity } \\
& \mathrm{X}_{2} \quad=\text { Funding planning } \\
& \mathrm{X}_{3} \quad=\text { Politics of Budgeting } \\
& \mathrm{X}_{4} \quad=\text { Public Transparency } \\
& \mathrm{e}=\text { Error term }
\end{aligned}
$$

\section{Result and Discussion}

\section{Test Results of Data Validity and Reliability}

Based on the validity test result of all items from the statement of research variables all items can be valid except the variable human resource capacity for indicators or items X1.5 and X1.6. The $r$ count values are 0.189 and 0.248 , respectively, below the critical $r$ of 0.3 , hence in the further analysis the two items of the instrument are treated. Meanwhile, the results of the reliability test showed that the attributes of the instrument variables were stated to be reliable.

\section{Test of Classic Assumption}

The normality test result is using Kolmogorov-Smirnov (K-S) non-parametric statistical test data which is normally distributed because the probability of Sig is greater than alpha $(0.536>0.05)$. Then, from the multicollinearity test result is found that there is no multicollinearity between independent variable since the value of Variance Inflation Factor (VIF) less than 10 and the tolerance value is greater than 0.10 . Meanwhile, the Glejser test results do not occur Heteroscedasticity because the significance value for each independent variable is greater than $\alpha 0.05$.

Hypothesis test (see tables 1, 2).

Coefficient determination test $\left(\mathrm{R}^{2}\right)$ 
Test result of coefficient determination

\begin{tabular}{|c|c|c|c|c|}
\hline Model R & $\mathbf{R}$ & R Square & Adjusted R Square & $\begin{array}{l}\text { Std. error } \\
\text { of the estimate }\end{array}$ \\
\hline 1 & $659^{\mathrm{a}}$ &, 435 & ,416 & ,29628 \\
\hline
\end{tabular}

Table 2

Test Result F ANOVA ${ }^{\mathrm{a}}$

\begin{tabular}{lllllll}
\hline & Model & Sum of squares & Df & Mean square & F & Siq \\
\hline 1 & Regression & 8,243 & 4 & 2,061 & 23,476 &, $000^{\mathrm{b}}$ \\
\hline Residual & 10,710 & 122 &, 088 & & \\
\hline Total & 18,953 & 126 & & & \\
\hline
\end{tabular}

a. Dependent Variable $S D$

b. Predictors: (Constant), TP, PP, KSD M, PA

From the ANOVA test or the $\mathrm{F}$ test in the table 2, the $\mathrm{F}_{\text {count }}$ value of 23.476 was obtained with a probability of 0,000 . Since the probability is less than 0,05 then the regression model can be used to predict the synchronize document APBD and KUA-PPAS or that human resources variable, funds planning, politic funds, and public transparency in together affects synchronization of the document APBD and KUA-PPAS.

From the test result in table 3, it can be explains in which the effect of each independent on dependent variable is: human resources capacity variable with significant values $0,028<\alpha 0,05$ and value $t_{\text {count }}(2,224)>$ value $t_{\text {table }}(1,657)$ means that human resources capacity has positive significant effect on synchronize document APBD and KUA-PPAS.

Planning fund variable with a significant value $0,000<\alpha 0,05$ and value $t_{\text {count }}(4,174)>$ value $t_{\text {table }}(1,657)$, means that fund planning has positive effect on synchronize document APBD and KUA-PPAS.

Political fund variable with a significance value of $0.028<\alpha 0.05$ and $t_{\text {value }}$ (2.228) $>\mathrm{t}_{\text {table }}$ value (1.657) means that budgeting politics has a significant positive effect on synchronizing the APBD document with the KUA-PPAS document.

Public transparency variable with a significance value of $0.001<\alpha 0.05$ and $\mathrm{t}_{\text {value }}(3.313)>\mathrm{t}_{\text {table }}$ value (1.657) means that public transparency has a significant positive effect on synchronizing the APBD document with the KUA-PPAS document.

Based on the test results in table 3 , the multiple regression equation is obtained as follows:

$$
\mathrm{Y}=-0.188+0.176 \mathrm{X} 1+0.424 \mathrm{X} 2+0.209 \mathrm{X} 3+0.249 \mathrm{X} 4+\mathrm{e}
$$

\section{Discussion}

This research is using more than one independent variable, in order to know the ability of the independent variable to predict the dependent variable, the value used is adjusted value $R^{2}$. The adjusted value $R^{2}$ of 0,416 it means that the dependent 
variable is able to explains by independent variable of $42 \%$. In other words $42 \%$ changes in the variable synchronization of APBD documents with KUA-PPAS documents can be explained by variables of human resources capacity, fund planning, politic fund, and public transparency and the rest of amount is $(100 \%-42 \%)=58 \%$ it explained by other factors not included in this study. Then how the effect of independent variable on dependent variable describes as below (see table 3).

Table 3

Test Result t Coefficients ${ }^{\mathrm{a}}$

\begin{tabular}{lllllll}
\hline \multirow{2}{*}{ Model } & \multicolumn{2}{l}{ Unstandardized coefficients } & $\begin{array}{l}\text { Standardized } \\
\text { coefficients } \\
\text { Beta }\end{array}$ & T & Sig. \\
\cline { 2 - 5 } $\mathrm{B}$ &,- 188 &, 372 & &,- 506 &, 614 \\
\hline $\mathbf{1}$ & (Constant) &, 176 &, 079 &, 179 & 2,224 &, 028 \\
\hline KSDM &, 424 &, 102 &, 362 & 4,174 &, 000 \\
\hline PA &, 209 &, 094 &, 159 & 2,228 &, 028 \\
\hline PP &, 249 &, 075 &, 240 & 3,313 &, 001 \\
\hline TP & & & & \\
\hline
\end{tabular}

a. Dependent Variable: $S D$

The Influence of Human Resources Capacity, Budget Planning, Political Budgeting, and Public Transparency to Synchronize APBD Documents with KUA-PPAS Documents

From the ANOVA test result or $\mathrm{F}_{\text {test }}$ on table above, it is obtained that the Value $F_{\text {count }}$ of 23,476 with significant level is 0,000 . Since the probability 0,000 is less than $\alpha 0,05$, the result of regression model shows the coefficient from human resources capacity, fund planning, politic fund and public transparency have positive numeric, funds planning, politic fund, and public transparency on synchronize the document of APBD and KUA-PPAS shows positive results. This indicates the better the capacity of human resources, budget planning, political budgeting, and public transparency, the synchronization of APBD documents with KUA-PPAS documents will be realized. The results of this study were in line with the research of Iskandar [4] in which the results of the hypothesis test were simultaneously the capacity of human resources, fund planning, and politic fund has significant effect on synchronize document of APBD and KUA-PPAS. However, the results of this study contradicted with Arniati et al. [5] in which the variable capacity of human resources, funds planning, politic fund and supporting information did not has the significant effect on synchronize the document of APBD and KUA-PPAS.

\section{The Effect of Human Resources Capacity on Synchronize Document of APBD and KUA-PPAS}

In order to find out the influence of human resource capacity variables on the synchronization of APBD documents with KUA-PPAS documents, it can be seen from $t_{\text {count }}$ value result and the significance of $t_{\text {count }}$ value. In the table 1 is obtained influence of human resource capacity on synchronizing document of APBD and KUA-PPAS is positive and significant. It is reflected on the correlation coefficient 
of 0,716 and $t_{\text {-count }}$ value $(2,224)<t_{\text {table }}(1,657)$ with the significant value of $0,028<$ $\alpha 0,05$. The positive effect shows the human resources capacity has positive correlative on synchronize the document of APBD and KUA-PPAS, it indicates that if the professional and competent government apparatus in preparing the RKA-SKPD will have a positive impact on synchronizing APBD documents and KUA-PPAS. The significant effect shows that quality and capacity of human resources have the important role to increase synchronize of the document APBD and KUA-PPAS. The results of this study are not in line with the research of Arniati et al. [5] where human resource capacity did not have a significant positive effect on the synchronization of APBD documents and KUA-PPAS documents.

This research has the same result of Iskandar [4] and Elfrina [2] which stated that the human resources capacity has significant effect on synchronize document of APBD and KUA-PPAS. It indicates that the APBD planning have the quality, and each SKPD must have the human resources that able to carry out the task, by conducting counseling on regional financial management.

\section{The Effect of the Funds Planning on Synchronize the Document of APBD and KUA-PPAS}

The result of test $t$ on the table 2 shows the effect of the funds planning variable on synchronize the document of PBD and KUA-PPAS are positive and significant. Those things can be seen from the correlation coefficient of 0,424 with the significant value of $0,000<\alpha 0,05$ and the $t_{\text {count }}$ value $(4,174)<t_{\text {table }}(1,657)$, this means that synchronize the document of APBD and KUA-PPAS, in the other word funds planning is able to synchronized the document of APBD and KUA-PPAS. It suspected because the government and DPRD is already consistent and have the high commitment in the process of planning and fund as determined in Permendagri Number 27/2013 regarding the Guidelines for Preparing the Revenue Budget and Regional Expenditures for Fiscal Year 2014, which requires in arranging the General Policy APBD (KUA) and the interim budget priorities and funding ceiling (PPAS) of Government/city must be guided of the local government work development plan (RKPD) District/city. The formulation of the KUA-PPAS draft is intended to be done through synchronizing the achievement of targets and performance target between program and 2014 Government Work Plan activities by paying attention to regional development priorities and regional financial capabilities. Other opinion that the beginning of fund planning is a factor that largely determines the synchronization of APBD documents with KUA-PPAS.

The result is not in line with the research of Arniati et al [5] which fund planning has not the positive significant on synchronize the document of APBD and KUA-PPAS and the research result of Iskandar [4] which stated that the fund planning has negative effect on synchronize the document of APBD and KUA-PPAS.

However, this research is in line with the research of Elfrina [2] which is stated the significant effect shows that higher of fund planning, hence it will increase the synchronize document of APBD and KUA-PPAS. In this case, if in the early steps, the planning has been arranged properly it will also create good impact on the subsequent budgeting planning. 


\section{The Effect of Political Fund on Synchronize Document of APBD and KUA-PPAS}

The $t$ test result in the table above shows the political effect on synchronize the document of APBD and KUA-PPAS is positive and significant. It is revealed from the correlation coefficient value of 0,209 and $t_{\text {count }}$ value $(2,228)>t_{\text {table }}(1,657)$ with the significant value of $0,028<\alpha 0,05$ means that the political funds have significant positive effect on synchronize the document of APBD and KUA-PPAS. The positive effect shows the political fund has positive effect on synchronize the document of APBD and KUA-PPAS, in other words the legislative role in funding will affect synchronization of the document of APBD and KUA-PPAS. The significant effect shows that the political funds have the important role to increase the synchronize document of APBD and KUA-PPAS.

This result is in line with the opinion of Amirudin [3] which the main role of legislative in the process of arranging APBD is clear during the discussion of KUAPPAS as well as in the stipulation of the Regional Regulation (Perda) of (APBD). However, the result is not in line with Arniatietal [5] which the political fund did not has the positive significant effect on synchronize the document APBD and KUA-PPAS.

Moreover, the result is in line with the research of Elfrina [2] which has the significant effect shows that the political fund have the role in increase the synchronize the document of APBD and KUA-PPAS, which is the legislative role of DPRD member in funding will effect on synchronize the document of APBD and KUA-PPAS.

\section{The Effect of Public Transparency on Synchronize the Document of APBD and KUA-PPAS}

The $t$ test results on the table above shows the public transparency effect on synchronize the document of APBD and KUA-PPAS is positive and significant. It is revealed from the correlation coefficient of 0,249 and $t_{\text {count }}$ value $\left((3,313)>t_{\text {table }}\right.$ $(1,657)$ with the significant value of $0,001<\alpha 0,05$ means that the public transparency has significant positive effect on synchronize the document of APBD an KUA-PPAS. This is suspected since Musi Banyuasin District Government has openness in making regional financial policies, especially in the preparation of RKA-SKPD, until the financial policies is known by DPRD and citizen. Those phenomenon in accordance to Regulation of the Minister of Home Affairs (Permendagri) number 13/2006 regarding the Regional Financial Management Guidelines which mandates to Regional Government (Pemda) to implement the socialization of RAPBD before submitting to DPRD and citizen because APBD are public document, which the citizen have the right to known the information inside. The citizen rights to access the public documents are guarantee by Constitutions Number 14/2008 regarding the Openness of Public Information. The results are in line with the opinion of Sopanah and Mardiasmo [1] which requires that the budget prepared by the executive is said to be transparent if it meets the following criteria:

1) Availability of budget policy announcement, 2) Availability of budget documents and easily accessible, 3) Availability of timely accountability reports, 
4) Accommodating community voices / proposals, and 5) Availability of a system for providing information to the public.

The results are not in line with the research of Iskandar [4] in which the interaction test result shows that public transparency is cannot moderate the relationship between human resource capacity, fund planning and political funds on synchronize the document of APBD and KUA-PPAS. Thus, the public transparency is not the moderate variable.

\section{Conclusion}

From the results, some conclusions that can be taken are as follows:

1) The hypothesis test results in simultaneously to the human resources capacity, fund planning, political funds, and public transparency has significant effect on the document of APBD and KUA-PPAS document's synchronization.

2) The hypothesis test results in partial to the human resources capacity, fund planning, political fund and public transparency has significant effect on the APBD and KUA-PPAS documents' synchronization.

\section{The Research Implication}

The findings of this study prove that human resource capacity, funds planning, political funds, and public transparency between executive and legislative come to the agreement and consistency regarding with the general budget policies and priorities, it will become guidelines for the preparation of the APBD gives the significant effect on synchronize the document of APBD with the document of KUA-PPAS on the Musi Banyuasin District Government. Theoretically, the finding can give the clearance on the thinking concept regarding with the important of APBD and KUA-PPAS documents' synchronization. In addition, it should be known that the concept of agency theory is a form of private sector management system adopted by the public sector as the design of an appropriate contract to align the interests of principals and agents in the event of a conflict of interest.

Practically, these finding results expected to provide the contribution for Musi Banyuasin District Government to increase the human resources capacity, funds planning, political funds, and public transparency on synchronize the document of APBD and KUA-PPAS. Moreover, it is hoped able to be used by the regional government to evaluate the future evaluation related to factors influence synchronization document of APBD and KUA-PPAS. Likewise, in terms of policy, this results hope can be useful as contribution of ideas for policy makers, especially in Musi Banyuasin District Government and DPRD should be consistent and have a high commitment in preparing the Revenue Budget and shopping regional and information about the regional financial policy to be conveyed to the public in accordance to the foundation, rules and mechanisms as governed in the legislation.

\section{The Limitation of Research and Suggestion}

The limitation that must be observed and the suggestion on the limitation that the researcher found, including: 
The scope of this research carries out only one Musi Banyuasin District. Therefore, to get general conclusions it is necessary to conduct more extensive research.

The lack of knowledge of respondent's questionnaire and lack of seriousness to answers all the questions. It is possible that the answers given by respondents are not honest, so it does not produce answers that are consistent with this study. The subjectivity problem of the respondents can result in the results of this study being vulnerable to the bias of respondents' answers.

This research does not explore other factors that might influence the synchronization of the APBD document with the KUA-PPAS document, for example performance achievements.

The suggestion from further research regarding with the topics are:

(1) The further research can be developed the result with adding the research object, such as the other region outside Musi Banyuasin District Government.

(2) The further research is expected can development the better research instrument with collecting more the references related with the same research, thus hope to be obtained better understanding about the factors has the effect synchronize the document of APBD and KUA-PPAS.

(3) The further researcher is expected to be able to develop the research variable, not only limited to the factor of human resources capacity, funds planning, political fund and public transparency, but also the possibility to the test performance variable, hence the further researcher will obtain better understanding about the factors that influencing the APBD and KUA-PPAS documents' synchronization.

\section{REFERENCES}

[1] Mawarni D., Syukriy A. Pengaruh Pendapatan Asli Daerah Dan Dana Alokasi Umum Terhadap Belanja Modal Serta Dampaknya Terhadap Pertumbuhan Ekonomi Daerah (Studi Pada Kabupaten Dan Kota di Aceh). Akuntansi. 2013; 23 (2): 164 (In Ind.).

[2] Elfrina L., Ratnawati V., Wiguna M. Pengaruh Kapasitas Sumber Daya Manusia, Perencanaan Penganggaran, Politik Pengaggaran, Dan Informasi Pendukung Dengan Transparasi Publik Sebagai Variabel Moderating Terhadap Sinkronisasi Dokumen APBD Dengan Dokumen KUA-PPAS. Jurnal Online Mahasiswa Fakultas Ekonomi. 2014; 2 (1): 1-16 (In Ind.).

[3] Amirudin. Identifikasi dan Analisis Faktor-faktor yang Mempengaruhi Sinkronisasi Dokumen Anggaran Pendapatan dan Belanja Daerah dengan Dokumen Kebijakan Umum Anggaran dan Prioritas Plafon Anggaran Sementara (Studi Kasus Provinsi D.I Yogyakarta TA 2008). Yogyakarta: Universitas Gajah Mada; 2009 (In Ind.).

[4] Iskandar Metodologi Penelitian Pendidikan dan Sosial. Jakarta: Referensi; 2013 (In Ind.).

[5] Arniati E. Imelda Pengaruh Kapasitas Sumber Daya Manusia, Politik Penganggaran, Perencanaan dan Informasi Pendukung Terhadap Sinkronisasi Dokumen APBD Dengan Dokumen KUA-PPAS di Lingkungan Pemerintah Kota Tanjungpinang. Simposium Nasional Akuntansi (SNA) XIII. Purwokerto: Univesitas Jenderal Soedirman Purwokerto; 2010 (In Ind.).

[6] Simamora H. Manajemen Sumber Daya Manusia (Edisi III). Yogyakarta: SKIE YKPN; 2001 (In Ind.).

[7] Budiardjo M. Dasar-Dasar Ilmu Politik. Jakarta: PT. Gramedia Pustaka Utama; 2008 (In Ind.). 
[8] Handayani B. Pengaruh Reformasi Penyusunan Anggaran terhadap Kualitas APBD Kota Semarang. Jurnal Dinamika Akuntansi. 2009; 1 (1): 3140. DOI: 10.15294/ jda.v1i1.1910 (In Ind.).

[9] Sugiyono Metode Penelitian dan Pengembangan (Research and Development/R\&D). Bandung: Alfabeta; 2016 (In Ind.).

\title{
Article history:
}

The article was submitted on 01.04.2020.

The article was accepted on 01.06.2020.

Научная статья

\section{Влияние кадрового потенциала, бюджетного планирования, политического бюджетирования и прозрачности для общественности на документы APBD и синхронизацию KUA-PPAS в правительстве района Муси Банюасин, Индонезия}

\author{
М. Сюро \\ Колледж социальных и гуманитарных наук \\ (STISIPOL Candradimuka Palembang) \\ Свадая Секип Уджин, 20, Палембанг, Индонезия, 30127
}

\begin{abstract}
Аннотация. Цель данного исследования - определить влияние кадрового потенциала, бюджетного планирования, политического бюджетирования и общественной прозрачности на синхронизацию между документом о бюджете региональных доходов и расходов, общей политикой бюджета региональных доходов и расходов и утвержденным бюджетом. Исследование проводится на основе анализа района Муси Банюасин в Индонезии. В исследовании приняли участие советники и должностные лица / сотрудники, участвующие в подготовке плана работы над бюджетом, в который было включено 33 региональных подразделения. Выборка включала в себя 127 представителей региональных подразделений. В исследовании используют первичные данные, полученные данные были проанализированы через множество циклов линейной регрессии. Гипотезы одновременно и частично проверяются F-тестом и $\mathrm{t}$-тестом. Результаты проведенного исследования показали, что параллельное использование потенциала человеческих ресурсов, бюджетного планирования, политического бюджетирования и прозрачности для общественности оказывает положительное и существенное влияние на синхронизацию бюджетных документов, бюджетной политики и утвержденного бюджета. Результаты и концептуальный вклад данного исследования могут быть полезны в сфере государственного управления в Индонезии и других странах, особенно в деятельности правительства и парламента, так как они должны быть более последовательными и иметь высокую приверженность в отношении бюджетирования.
\end{abstract}

Ключевые слова: Индонезия, бюджет, региональные расходы, потенциал людских ресурсов, планирование бюджета, политика бюджетирования, общественная прозрачность

\section{История статьи:}

Статья поступила в редакцию: 01.04.2020.

Статья принята к публикации: 01.06.2020. 


\section{Информация об авторе:}

Сюро Mam - доктор наук, лектор Колледжа социальных и гуманитарных наук (STISIPOL Candradimuka Palembang) (Индонезия) (ORCID ID: 0000-0003-4169-5497) (e-mail: mmatsyuroh@gmail.com).

\section{Information about the author:}

Syuroh Mat - Doctor of Science, Lecturer in the College of Social and Political Sciences (Indonesia) (ORCID ID: 0000-0003-4169-5497) (e-mail: mmatsyuroh@gmail.com).

\section{Для цитирования:}

Syuroh M. The Effect of Human Resources Capacity, Budget Planning, Political Budgeting, and Public Transparency on the of APBD Documents and KUA-PPAS's Synchronization in Musi Banyuasin District Government // Вестник Российского университета дружбы народов. Серия: Государственное и муниципальное управление. 2020. Т. 7. № 3. С. 239253. DOI: $10.22363 / 2312-8313-2020-7-3-239-253$

\section{For citation:}

Syuroh M. The Effect of Human Resources Capacity, Budget Planning, Political Budgeting, and Public Transparency on the of APBD Documents and KUA-PPAS's Synchronization in Musi Banyuasin District Government. RUDN Journal of Public Administration. 2020; 7 (3): 239-253. DOI: 10.22363/2312-8313-2020-7-3-239-253 